\title{
Hisse Senedi Piyasasının Terrorizme Karşı Duyarlılığı/ Duyarsızlığı Üzerine: Türkiye Örneği
}

\section{On the (In)sensitivity of a Stock Market to Terrorism: Turkish Experience}

Mustafa YILDIRIM ${ }^{1}$

\begin{abstract}
This paper investigates the impact of terrorism that took place within Turkish borders on the Turkish stock market by utilizing the daily time series of terror attacks and the benchmark stock index between 2000 and 2015. The terror data taken from the Global Terrorism Database distinguishes itself in several aspects, including location, attack types, the number of attacks, the number of victims killed, and the number of victims injured. It is shown that the stock market became desensitized to terror attacks over time. The sensitivity that is observed for the period of 2000-2004 is lost for the remaining period of 2004-2015. The sensitivity period includes the 2001 financial crisis of Turkey after which various financial reforms were implemented. Hence, the lost sensitivity over the 2004-2015 period is considered to be associated with the changing state of the financial system. Moreover, it is found that the location of an attack is unimportant for the stock market. However, when attacks are classified into types based on tactics used during the attack, it is shown that the stock market is negatively sensitive to terrorism only when the attack type is facilities/ infrastructure. Since the conclusions are based on Turkey, they might have broader implications for developing countries.
\end{abstract}

Keywords: Terror; Turkey; Stock Markets; BIST; 2001 Crisis

\section{INTRODUCTION}

Being no stranger to humanity, there has been a sharp rise in terrorist activity suggesting that it is a new form of risk that investors may be facing. ${ }^{1}$ It is often reported in the economics literature that terrorism reduces the growth rate (Abadie and Gardeazabal 2008; Gaibulloev and Sandler 2009; Buesa et al.,2007). This reduction is likely to stem from its adverse impacts on macroeconomic variables such as consumption, investment, public spending, and on the capital inflows (Crain and Crain, 2006; Gaibulloev

$0000-0002-4545-401 X$

\begin{abstract}
ÖZET
Buçalışma, 2000-2015yılları arasında Türkiye sınırları içerinde meydana gelmiş olan terörizmin Türk hisse senedi piyasası üzerindeki etkisini, terör saldırıları ve hisse senedi piyasası gösterge endeksinin günlük zaman serilerinden faydalanarak incelemektedir. Terör verisi küresel terörizm veri tabanından (Global Terrorism Database) alınmış olup; lokasyon, saldııı türleri, saldırı, ölüm ve yaralanma sayıları gibi bilgileri içermektedir. Zaman içerisinde, hisse senedi piyasasının terör saldırılarına karşı duyarsızlaştığı gösterilmiştir. 2000-2004 periyodunda gözlenen duyarlılık geriye kalan 2004-2015 periyodunda ortadan kaybolmuştur. Duyarlılık gözlenen periyod, sonrasında çeşitli finansal reformların uygulandığı 2001 Türk finansal krizini içermektedir. Dolayısıyla, 2004-2015 periyodundaki duyarlıık kaybının, Türk finansal sisteminin değişkenlik gösteren durumu ile ilişkili olabileceği düşünülmüştür. Bununla birlikte, saldırının lokasyonunun hisse senedi piyasası için önemsiz olduğu bulunmuştur. Fakat saldırılar türlerine göre sınıflandırıldığında, hisse senedi piyasasının sadece altyapıyı hedef alan saldırılara karşı negatif duyarlılı̆ının olduğu gösterilmiştir. Bulgular Türkiye özelinde elde edildiğinden, gelişmekte olan ülkeler için geniş uygulama alanları bulabilir.
\end{abstract}

Anahtar Kelimeler: Terör; Türkiye; Borsa; BIST; 2001 Krizi

and Sandler, 2008; Abadie and Gardeazabal 2008). Due to its nature, some markets such as tourism (Enders and Olson 2012) may be more responsive to terror attacks. For example, Drakos and Kutan (2003) finds that because of the transnational terror attacks between 1991 and 2000, Greece, Turkey, and Israel lost $\% 9, \% 5$, and $1 \%$ of their tourism market shares, respectively.

Financial markets, in particular, stock markets can also be expected to show higher sensitivity to terrorism. As argued by Karolyi (2006), when the 
terror incident occurs, the high liquidity of stock markets enables the investors to reshuffle their portfolios in a timely manner in search of more stable financial instruments. In fact, the record high loss experienced by the US stock market after the terror attacks of September 11, 2001 (also known as 9/11) has made it visible to everyone that how detrimental consequences a terrorist act may have for stock markets. ${ }^{2}$ Hence, beginning with the $9 / 11$, financial economists have turned their attention to the impact of terrorism on stock markets. The prevalent view in the emerging literature is that terror incidents have a significant negative impact on stock markets. For example, Chen and Siems (2004) show that the US financial market is negatively affected by terror incidents but it is more resilient than it used to be and thus recommends the policymakers to copy the US model of flexible and effective monetary authority. Eldor and Melnick (2004) examine Israel and find that Israeli stock market is negatively sensitive to terrorism. Brounen and Derwall (2010) focus on the major economies of the world and show a mildly negative effect of terrorism on stock markets. Moreover, they compare the size of this effect with that of other disasters such as earthquakes and report that the size is more pronounced following terror attacks. Aslam and Kang (2015), Zussman and Zussman (2006), Drakos (2010), Karolyi and Martell (2010), Eldor et al. (2012) are among many others to find this negative impact. Besides confirming this negative impact, a bunch of studies also examine whether the terror acts affect the volatility of the stock returns (Essaddam and Karagianis 2014; Barros and Gil-Alana, 2009; Nguyen and Enomoto 2009; Arin et al. 2008; Nikkinen et al. 2008). The answer appears affirmative.

As stated by Aslam et al. (2015), the studies on the potential effects of terrorism on stock markets have its roots mostly in the context of a developed country. However, it can be argued that these potential effects are not homogeneous across all countries, especially between those that are developed and those that are developing. In fact, this argument seems to be supported by very recent studies that have failed to show the impact of terrorism on developing countries' stock markets. Alam (2012) finds that Pakistan's stock market is insensitive to terror in the short run. Aksoy (2014), focusing on Turkey as in the current study, reports that although some terror attacks have a high negative effect on the stock market returns at the attack date, this effect is not statistically significant for most of them. Similarly, restricting attention to
Turkey, Eruygur and Omay (2014) conclude that not all terrorist activity affect the stock market.

The objective of this paper is to investigate the impact of terrorism on the stock market of a developing country, particularly on that of Turkey between 2000 and 2015. In particular, this paper intends to answer the following questions:

(1) Does terrorism have an effect on the Turkish stock market?

(2) Does the location of the terror incident matter?

(3) Does the attack type matter?

To my knowledge, this is the first paper that examines the effect of attack types on the Turkish stock market. The answers are of particular importance for developing countries as well as emerging markets as Turkey serves as an ideal example for both.

In terms of the utilized methodology in addressing these questions, in this work, I depart from the bulk of the literature that employs event study methodology. I employ time series regression analysis. This departure is necessary because terror attacks in Turkey for the period of interest follows a continuous stream. So, as argued by Eldor and Melnick (2004), terror attacks in such a case cannot be considered as sporadic events suggesting that their impact can be studied by time series regression analysis rather than an event study analysis. To endogenously detect potential structural breaks, I conduct multiple break tests devised by Bai (1997), Bai and Perron (1998).

The main results of my work are as follows. I find that the Turkish stock market is negatively sensitive to terrorism for the period of 2000-2004. For the period of 2004-2015, however, this sensitivity disappears, and the stock market becomes insensitive to terrorism. The insensitivity result is robust according to alternative measures of terror but is not in line with the literature that often reports a significant negative link between terror and the stock markets' performance. Given that the period of sensitivity includes the Turkish financial crash of 2001, one explanation may be related to the state of the Turkish financial system. More specifically, it can be argued that the Turkish stock market is more susceptible to negative shocks such as terror events in times when the financial system is more fragile. Another explanation may be related to the increasing level of integration of Turkish stock market with its international counterparts over time (Arshad 2017). It is known that financial integration can foster financial stability and can induce the econ- 
omy to be more resilient to the negative shocks by paving the way for more efficient resource allocation (Park and Lee 2011). Aside from the two explanations pertinent to the financial system, Turkish stock market may have simply desensitized to terrorism over time through so-called learning effect. As terror has been the part of their daily lives, investors might have been accustomed to live with it. Thus, the investors might take a given terrorist activity less of a surprise and hence may start ignoring them as time goes on. Interestingly, I also find that the location of a terrorist activity does not matter for its impact on the stock market. This finding invalidates the location-based explanations. In particular, it shows that the insensitivity result is not simply driven by the fact that most terror attacks occurred in less developed geographic regions of Turkey. Finally, I find that during the period of insensitivity, facility/infrastructure attacks are the only attack types to which the stock market reacts significantly. This seems to be in line with the intuition that when the attack type is facility/infrastructure, even those firms with no investment in the region of a terror attack and their investors are likely to believe that terrorists have changed their tactics and their investment might be the next target.
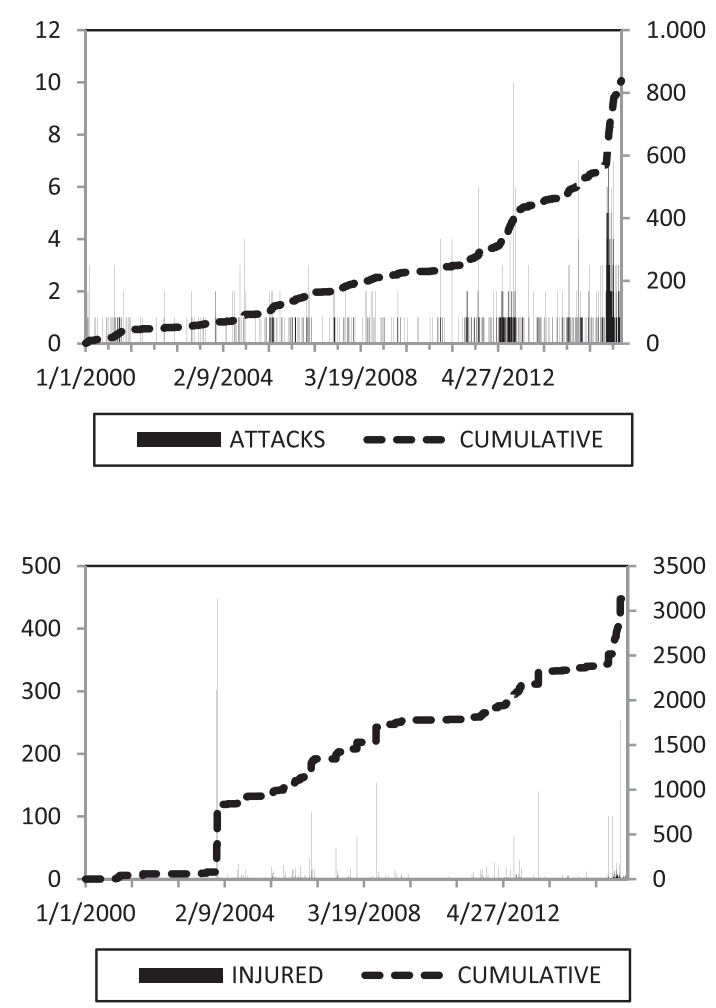

The remainder of the paper is organized as follows. An overview of terrorism in Turkey is presented in the next section, followed by an overview of the stock market in Turkey. The data is presented in Section 4. Section 5 describes the methodology and presents results. Section 6 concludes.

\section{OVERVIEW OF TERRORISM IN TURKEY}

Mostly tied with the Partiya Karekeren Kurdistan (PKK), a Kurdish separatist group, Turkey has suffered from terrorism for many years. In particular, over the last three decades, many Turkish citizens have been killed by a nearly continuous stream of terrorism-related events. Most of these events took place in the eastern and southeastern Anatolia, which have been among Turkey's least-developed regions.

The aspects of time series dimension of terror in Turkey between 2000 and 2015 are presented in Fig. 1. It illustrates the number of attacks, the number of victims killed, the number of victims injured, and the terror index of Eckstein and Tsiddon (2004), which is defined as the natural logarithm of ( + the equal weighted sum of the number of attacks, the number victims killed, and the number of victims injured). Fig. 1 confirms that there was indeed a continuous stream of terror events between 2000 and 2015.
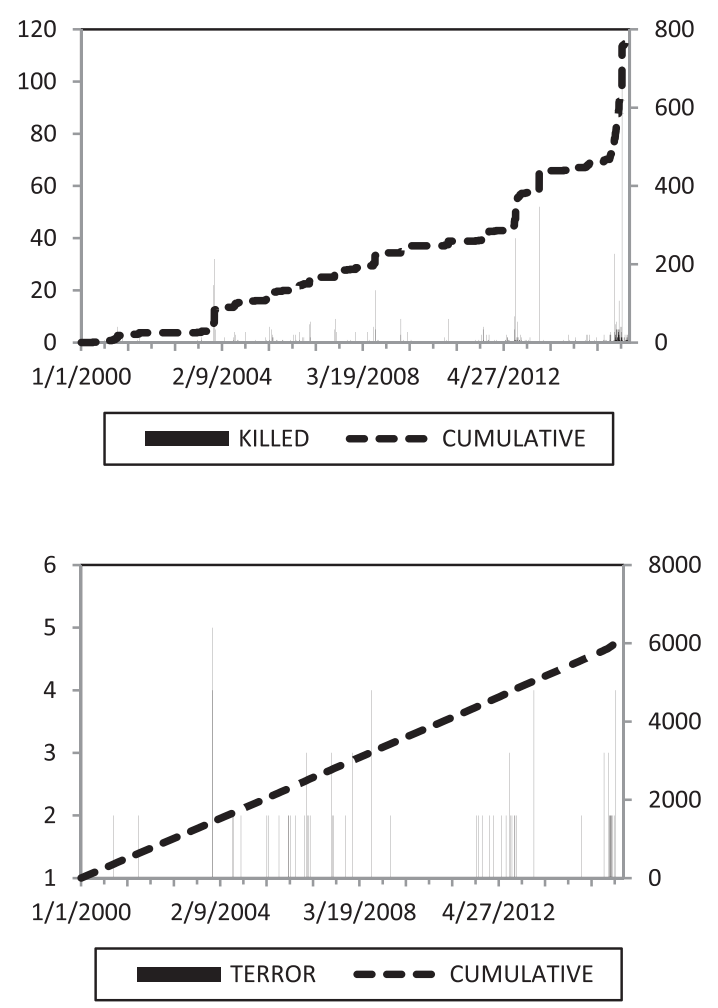

Fig. 1: Terror attacks, victims killed, victims injured and terror index. 
The number of terror attacks with respect to their characteristics is presented in Table 1. The classification of data is as follows:

1. by city type (Major: Ankara, Istanbul, Izmir; Other: elsewhere; Unknown: the location of the attack is unknown),

2. by region (East: eastern and southeastern Anatolia; West: the remaining geographic regions; Unknown: the location of the attack is unknown), and

3. by attack type (armed assault, assassination, bombing, facility/infrastructure attack, hostage taking, and other).

Table 2 represents damage rates as measured by the number of victims killed or injured per attack with respect to each category. It demonstrates that, on average, a terrorist attack was associated with a higher damage if it took place in a major city or in a geographic region other than eastern or southeastern Anatolia. As for the attack types, it shows that the damage rate was highest for the bombing, whereas it was lowest for facility/infrastructure attacks.

Table 1: Summary of terror attacks by categories (January 2000 - December 2015)

\begin{tabular}{|c|c|c|}
\hline \multirow{3}{*}{ City Type $^{a}$} & Major & 199 \\
\hline & Other & 536 \\
\hline & Unknown & 104 \\
\hline \multirow[t]{3}{*}{ Region $^{a}$} & East & 475 \\
\hline & West & 260 \\
\hline & Unknown & 104 \\
\hline \multirow[t]{6}{*}{ Attack Type } & Armed Assault ${ }^{\mathrm{b}}$ & 206 \\
\hline & Assassination ${ }^{c}$ & 28 \\
\hline & Bombing $^{d}$ & 409 \\
\hline & Facility/Infrastructure & 49 \\
\hline & Hostage Taking $^{f}$ & 121 \\
\hline & Other $^{g}$ & 26 \\
\hline Killed $^{\mathrm{h}}$ & & 796 \\
\hline Injured $^{\text {h }}$ & & 3207 \\
\hline Attacks $^{h}$ & & 839 \\
\hline \multicolumn{3}{|c|}{$\begin{array}{l}\text { a Qualitative categories are treated as dummy variables in the } \\
\text { econometric analysis. } \\
\text { b A firearm, incendiary, or sharp instrument (knife etc.), grenades, } \\
\text { projectiles, and unknown or other explosive devices that are } \\
\text { thrown. } \\
\text { 'An act whose primary objective is to kill one or more specific, } \\
\text { prominent individuals. } \\
\text { d An attack where the primary effects are caused by an energetically } \\
\text { unstable material undergoing rapid decomposition other than } \\
\text { explosive devices that are thrown. } \\
\text { e An act, excluding the use of an explosive, whose primary objective } \\
\text { is to cause damage to a nonhuman target. } \\
\text { f Barricade incident, kidnapping. } \\
{ }^{9} \text { Hijacking, unarmed assault, unknown. } \\
\text { } \text { Numerical variables are treated as continuous variables in the } \\
\text { econometric analysis. }\end{array}$} \\
\hline
\end{tabular}

Table 2: The Damage rate ${ }^{a}$ of attacks by categories $^{b}$ (January 2000 - December 2015)

\begin{tabular}{llcc}
\hline & & Killed & Injured \\
\hline City Type $^{c}$ & Major & 1.26 & 7.77 \\
& Other & 0.93 & 2.95 \\
Region $^{c}$ & East & 0.86 & 2.43 \\
& West & 1.31 & 7.58 \\
Attack Type & Armed Assault & 1.12 & 1.50 \\
& Assassination & 0.86 & 1.82 \\
& Bombing & 1.25 & 6.78 \\
& Facility / Infrastructure & 0.00 & 0.06 \\
& Hostage Taking & 0.03 & 0.17 \\
& Other & 0.96 & 1.92 \\
\hline
\end{tabular}

a The damage rate is defined as the number of victims killed or injured per attack type.

b See Table 1 for definitions.

'Unknown city and region types are not shown.

Table 3 shows the proportion of victims killed, victims injured, and attacks by categories. For example, given that an attack took place, the probability that it was in the major city is 0.32 ; given that people got killed in an attack, the probability that the attack was in the major city is 0.34; given that people got injured in an attack, the probability that the attack was in the major city is 0.49 .

Table 3:a,b Proportion of people killed, injured, and days of a terror attack by categories (January 2000 December 2015)

\begin{tabular}{|c|c|c|c|c|}
\hline & & Killed & Injured & $\begin{array}{l}\text { Day of } \\
\text { attacks }\end{array}$ \\
\hline \multirow[t]{2}{*}{$\begin{array}{l}\text { City } \\
\text { Type }^{c}\end{array}$} & Major & 0.34 & 0.49 & 0.32 \\
\hline & Other & 0.66 & 0.51 & 0.68 \\
\hline \multirow[t]{2}{*}{ Region $^{c}$} & East & 0.54 & 0.63 & 0.42 \\
\hline & West & 0.46 & 0.37 & 0.58 \\
\hline \multirow[t]{6}{*}{$\begin{array}{l}\text { Attack } \\
\text { Type }\end{array}$} & Armed Assault & 0.29 & 0.10 & 0.24 \\
\hline & Assassination & 0.03 & 0.02 & 0.04 \\
\hline & Bombing & 0.64 & 0.86 & 0.48 \\
\hline & $\begin{array}{l}\text { Facility / } \\
\text { Infrastructure Attack }\end{array}$ & 0.00 & 0.00 & 0.06 \\
\hline & Hostage Taking & 0.01 & 0.01 & 0.14 \\
\hline & Other & 0.03 & 0.02 & 0.04 \\
\hline
\end{tabular}

a Proportions can be interpreted as conditional properties.

${ }^{\mathrm{b}}$ See Table 1 for definitions.

'Unknown city and region types are excluded.

Before proceeding to examine the effects of terror attacks and their types on the stock market, it will be 
useful to give a brief summary of the Turkish stock market.

\section{OVERVIEW OF THE STOCK MARKET IN TURKEY}

Previously known as Istanbul Stock Exchange (also known as IMKB), Borsa Istanbul (hereinafter BIST), is the only corporation in Turkey for securities exchange established to provide trading in equities, bonds and bills, revenue-sharing certificates, private sector bonds, foreign securities, and real estate certificates as well as international securities. The BIST was launched in 1985 and began trading securities publicly in 1986. In 1987, the exchange commenced publishing its benchmark stock index (BIST100) on a daily instead of a weekly basis, and, in 1994, the BIST switched to fully-automated electronic trading. ${ }^{3}$

Crashing in February 2001, Turkish financial system was not in a good shape in the early 2000s. Between 2000 and 2002, the market capitalization of the BIST was in a constant decrease trend, it reached 34.4 billion US\$ in 2002, down from 69.5 billion US\$ in 2000. The number of listed companies kept decreasing until 2003 reaching 285 in 2003. The strong market growth enjoyed by the BIST for several years to come ended by the 2008 global financial crisis and its market capitalization fell by $63 \%$ to 120 billion US\$ in 2008. Meanwhile, the BIST100 reported 50\% decline in Türk Lirası terms and reached 26864 points. At the end of 2008, the number of listed companies was 317.4

Being open to foreign capital flows, the BIST has become integrated with international stock markets. Due to the proximity and the interest of the European Union (EU) in Turkey, the degree of integration with EU is higher than the US and the Asia-Pacific (Arshad 2017). The speed of integration was reported to be higher for the major trading partners of Turkey (Kasman et al. 2009).

Table 4 lists the correlations between Turkey's BIST100 with the major trading partners'stock indices: French (CAC40), German (DAX) and the UK (FTSE100) for the period of January 2000 and December 2015. It shows that, among the three indices, FTSE100 is the one which has the highest correlation with BIST100. This is in line with the studies documenting that the BIST is more responsive to the developments in the UK capital market (Mlodkowski and Tastulekova 2012).
Table 4: The Correlation of International Stock Indices with BIST100 (January 2000 - December 2015)

\begin{tabular}{ll}
\hline CAC40 & 0.359 \\
DAX & 0.334 \\
FTSE100 & 0.371 \\
\hline
\end{tabular}

\section{DATA}

Two different data sets, one for the stock market and the other for terrorism are used in this paper. The stock market data set consists of daily index values of Turkey's BIST100 and daily values of three international indices: France's CAC40, Germany's DAX, and England's FTSE100. The data for BIST100 is obtained from the official website of Turkish Stock Market, www.borsaistanbul.com, and the corresponding data for the international stock index values (CAC40, DAX, and FTSE100) is obtained from www.finance.yahoo. com. The terrorism data set includes information about the terror attacks and is extracted from the Global Terrorism Database provided by the University of Maryland, which can be reached on http://www. start.umd.edu/gtd. In extracting the terrorism data, I excluded ambiguous cases. That is, I included only those attacks where there is essentially no doubt of terrorism.

The problem initially encountered was the lack of consensus on how to measure the level of terrorism. The attack dummy, the number of incidents, the number of victims killed, the number of victims injured, and the combination of them were used by scholars as a measure of terrorism. As mentioned earlier, Eckstein and Tsiddon (2004) used a terror index defined as the natural log of ( $\mathrm{e}+$ the equally weighted sum of the number of incidents, the number of victims killed, and the number of victims injured) as a terror index. In this paper, following the literature, the attack dummy, the number of victims killed, the number of victims injured as well as the terror index of Eckstein and Tsiddon (2004) are used as a measure of terrorism.

\section{METHODOLOGY AND RESULTS}

As illustrated by Fig. 1, terror incidents in Turkey followed a continuous stream suggesting that time series regression analysis can be applied to analyze their effects, if any, on the Turkish stock market. Hence, contrary to the bulk of the literature that measures the effect of a particular event or series of 
events on the variable of interest by utilizing an event study analysis (Fama et al. 1969; Brown and Warner 1980, 1985; Lyon et al. 1999, Chen and Siems 2004, Abadie and Gardeazabal 2003, Dravid 1987, Pound and Zeckhauser 1990), ${ }^{5}$ I investigate the potential impact of terror incidents on the Turkish stock market by utilizing time series regression analysis.

I follow the methodology used by Eldor and Melnick (2004). The basic model is given by Eq. (1) where $y_{t}$ is a non-stationary $I(1)$ variable with a positive drift $f_{t}$ and $u_{t}$ is a white noise.

$$
y_{t}=y_{t-1}+\beta f_{t}+u_{t}
$$

In this paper, $y_{t}$ represents the natural log of the stock market index (BIST100). Table 5 confirms my specification that $y_{t}$ is a non-stationary $I(1)$ variable as augmented Dickey Fuller test results for BIST100 index shows that the existence of unit root cannot be rejected for the natural log levels but is strongly rejected for the first differences.

Table 5: Testing for unit roots (January 2000 December 2015)

\begin{tabular}{lccc}
\hline & ADF & $\begin{array}{c}1 \% \\
\text { Critical } \\
\text { Level }\end{array}$ & $\begin{array}{c}5 \% \\
\text { Critical } \\
\text { Level }\end{array}$ \\
\hline Level - BIST100 $^{\mathrm{a}}$ & -2.57 & -3.96 & -3.41 \\
First Difference - BIST100 $^{\mathrm{b}}$ & -63.87 & -3.43 & -2.86 \\
Level - FTSE100 $^{\mathrm{a}}$ & -2.51 & -3.96 & -3.41 \\
First Difference -FTSE100 $^{\mathrm{b}}$ & -23.17 & -3.43 & -2.86 \\
\hline
\end{tabular}

${ }^{a}$ In natural log including constant and trend.

${ }^{\mathrm{b}}$ Natural log differences including constant.

Specification of $f_{t}$ requires delicate attention. As Turkish stock market is open to free capital movements $f_{t}$ is assumed to be the natural log difference of the FTSE100 index. FTSE100 index is chosen on purpose because it has the highest correlation with BIST100 among all three international indices for the period of study. Moreover, as mentioned earlier, BIST100 is more integrated with the EU stock markets, in particular with the London Stock Exchange. The specification (1) is supported by Granger Causality test results, which can be seen in Table 6. In Table 6, Dlog(.) denotes the first difference of the natural log.

Table 6: Granger causality tests (6 lags) (January 2000 - December 2015)

\begin{tabular}{lcc}
\hline Null Hypothesis & F-Statistics & Probability \\
$\begin{array}{l}\text { Dlog(FTSE100) does not } \\
\text { Granger Cause Dlog(BIST100) }\end{array}$ & 3.1752 & 0.0042 \\
$\begin{array}{l}\text { Dlog(BIST100) does not } \\
\text { Granger Cause Dlog(FTSE100) }\end{array}$ & 0.8934 & 0.4986 \\
\hline
\end{tabular}

The residual $u_{t}$ is a white noise. Denoting by $\mathrm{D}$ the first difference operator, and writing $u_{t}=\gamma T_{t}+\epsilon_{t}$ where $\gamma$ is a set of parameters and $T_{t}$ represents the terror measure: the attack dummy, the number of attacks, the number of victims killed, the number of victims injured, the terror index of Eckstein and Tsiddon (2004), the location dummies, or the attack type dummies, Eq. (1) can be transformed into Eq. (2):

$$
D y_{t}=\alpha+\beta f_{t}+\gamma T_{t}+\epsilon_{t}
$$

Following the literature, I generate 5-days per week. As some terror attacks occur at night after the stock market is closed, their effects, if any, may not be observed on the day of the attacks. Instead, their effect may be observed on the next day following the attacks. To capture these lagged effects, I transform Eq. (2) into Eq. (3), where, Dlog(.) denotes the first difference of the natural log as before.

$$
\begin{aligned}
& D \log (B I S T 100)_{t}=\alpha+\beta * D \log \\
& (F T S E 100)_{t}+\gamma_{0} T_{t}+\gamma_{1} T_{t-1}+\varepsilon_{t}
\end{aligned}
$$

To take into account the potential breaks in the regression relation, I perform the multiple structural break test $(L+1$ versus $L$ sequentially determined breaks) as outlined by Bai (1997) and Bai and Perron

\begin{tabular}{|c|c|c|c|c|c|c|c|}
\hline \multirow[b]{2}{*}{ Variable } & \multicolumn{2}{|c|}{$1 / 1 / 2000-10 / 07 / 2004$} & \multicolumn{2}{|c|}{$10 / 08 / 2004-9 / 25 / 2008$} & \multicolumn{2}{|c|}{$9 / 26 / 2008-12 / 31 / 2015$} & \multirow[b]{2}{*}{$\mathrm{DW}^{3}$} \\
\hline & $\gamma_{0}$ & $\gamma_{1}$ & $\gamma_{0}$ & $\gamma_{1}$ & $\gamma_{0}$ & $\gamma_{1}$ & \\
\hline Attack Dummy & $\begin{array}{c}0.0004 \\
(0.8714)\end{array}$ & $\begin{array}{l}-0.0015 \\
(0.5668)\end{array}$ & $\begin{array}{c}0.0026 \\
(0.2559)\end{array}$ & $\begin{array}{l}-0.0035 \\
(0.1319)\end{array}$ & $\begin{array}{c}0.0005 \\
(0.7320)\end{array}$ & $\begin{array}{c}0.0007 \\
(0.6023)\end{array}$ & 2.0495 \\
\hline
\end{tabular}
(1998). I allow up to 5 breaks, employ a trimming percentage of $15 \%$, and use the significance level of 0.05 .

Table 7: Regression with an attack dummy ${ }^{1,2}$

${ }^{1}$ Two breaks: 10/08/2004 and 9/26/2008.

${ }^{2} \mathrm{p}$ values in parenthesis.

${ }^{3}$ DW refers to Durbin-Watson statistics. 
I form three hypotheses. In the first hypothesis, I ask: is there any impact of terror on the stock market? To seek an answer, I first take $T_{t}$ to be an attack dummy which takes the value 1 if an attack occurs at time $t$ and 0 otherwise. The results shown in Table 7 indicate that terrorism has no significant impact on the stock market.

Next, I take $T_{t}$ to be one of the quantitative measures of terror: the number of attacks, the number of victims killed, the number of victims injured, and the terror index of Eckstein and Tsiddon (2004). For the number of attacks, terrorism has no significant impact on the stock market as in the case of attack dummy. However, for all other terror measures, terrorism has a significant negative impact on the stock market between $1 / 1 / 2000$ and 10/8/2004, while no significant impact is observed between 10/11/2004 and 12/31/2015.

To summarize, for all terror measures, the stock market does not react to terrorism and hence it is insensitive to terrorism between 2004 and 2015. For the period of 2000-2004, however, the stock market reacts negatively to the terrorism if the terror level is taken to be the number of victims killed, the number of victims injured, and the terror index. Several explanations can be offered for the fact that the stock market shows sensitivity to terrorism for the period of 2000-2004 but no longer does so for the period of 2004-2015. First, given that the Turkish financial system experienced a serious crisis in 2001; one explanation might be that terrorism's effect on the stock market was more pronounced when the financial system was fragile. A similar explanation might be the increasing degree of integration of the stock market with its international counterparts. In fact, it is known that over time Turkish stock market is better integrated with the US, Asia-Pacific, and the EU with the integration being highest with the EU (Arshad 2017). Finally, the desensitization of the Turkish stock market to terrorism over time might simply be yet another explanation, which cannot be ruled out given that terror has been the part of Turkish people's daily lives.

In the second hypothesis, I ask: does the location of an attack matter for the stock market? For location, I form two set of dummies based on whether the attack took place in a major city or whether it took place in East and West. Interestingly, regardless of the choice of the dummies, the location is unimportant for the impact of the terrorism. More specifically, terror attacks that took place in the major city (Ankara, Istanbul, and Izmir) were no different from those that took place in the remaining cities in the sense that their impact on the stock market was both insignificant.

Table 8: Regression with quantitative variables $1,2,3$

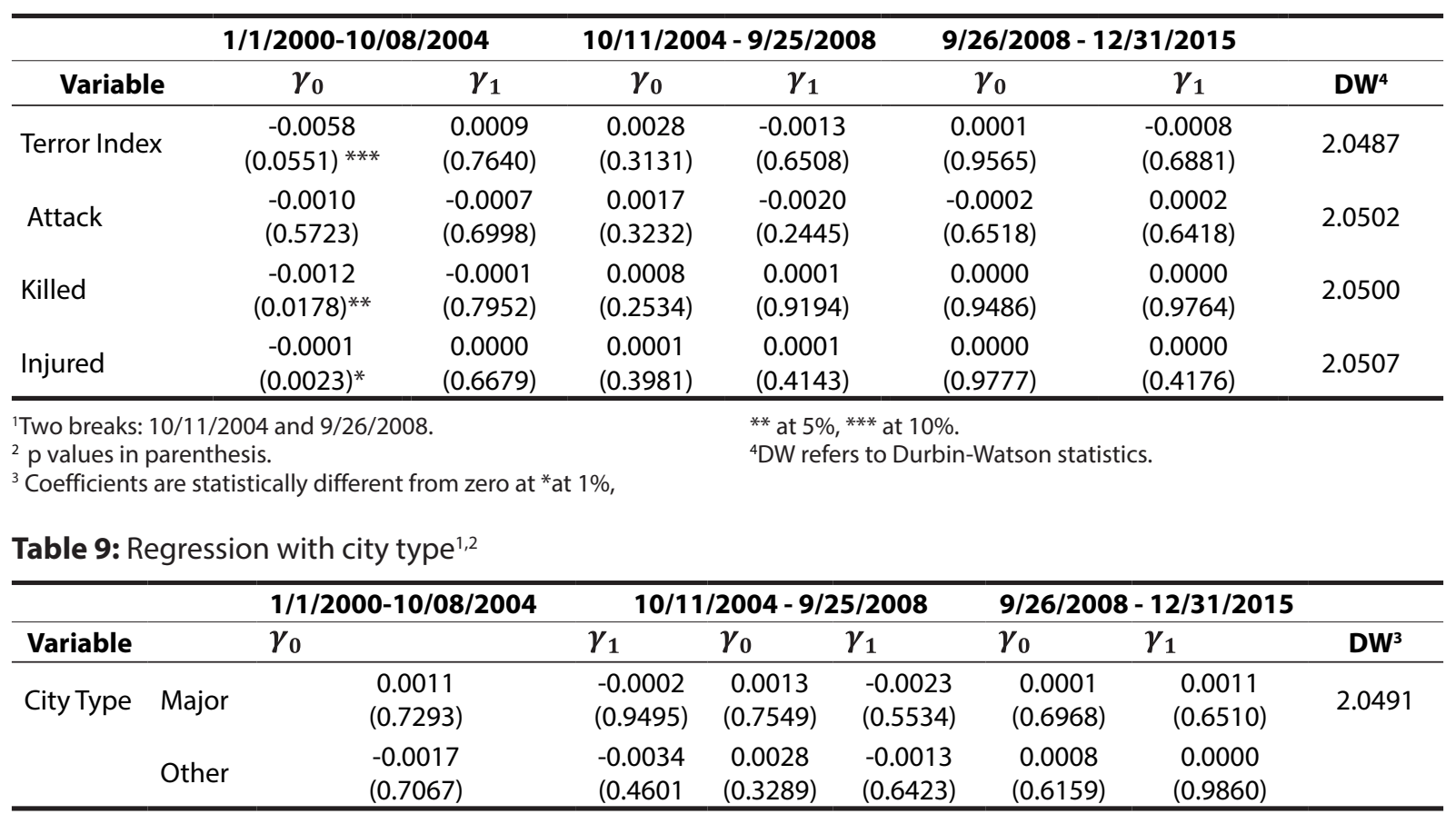

'Two breaks: 10/11/2004 and 9/26/2008.

${ }^{3}$ DW refers to Durbin-Watson statistics.

${ }_{2} \mathrm{p}$ values in parenthesis. 
Table 10: Regression with region ${ }^{1,2}$

\begin{tabular}{|c|c|c|c|c|c|c|c|c|}
\hline \multirow[b]{2}{*}{ Variable } & & \multicolumn{2}{|c|}{$1 / 1 / 2000-10 / 18 / 2004$} & \multicolumn{2}{|c|}{$10 / 19 / 2004-9 / 25 / 2008$} & \multicolumn{2}{|c|}{$9 / 26 / 2008-12 / 31 / 2015$} & \multirow[b]{2}{*}{ DW $^{3}$} \\
\hline & & $\gamma_{0}$ & $\gamma_{1}$ & $\gamma_{0}$ & $\gamma_{1}$ & $\gamma_{0}$ & $\gamma_{1}$ & \\
\hline \multirow[t]{2}{*}{ Region } & East & $\begin{array}{c}0.0045 \\
(0.4113)\end{array}$ & $\begin{array}{l}-0.0069 \\
(0.2119)\end{array}$ & $\begin{array}{c}0.0028 \\
(0.3622)\end{array}$ & $\begin{array}{c}0.0005 \\
(0.8759)\end{array}$ & $\begin{array}{c}0.0020 \\
(0.1987)\end{array}$ & $\begin{array}{l}-0.0004 \\
(0.7993)\end{array}$ & 2.0495 \\
\hline & West & $\begin{array}{l}-0.0007 \\
(0.7982)\end{array}$ & $\begin{array}{c}0.0003 \\
(0.9293)\end{array}$ & $\begin{array}{c}0.0015 \\
(0.6583)\end{array}$ & $\begin{array}{l}-0.0039 \\
(0.2573)\end{array}$ & $\begin{array}{l}-0.0021 \\
(0.3251)\end{array}$ & $\begin{array}{c}0.0011 \\
(0.6168)\end{array}$ & \\
\hline
\end{tabular}

${ }^{1}$ Two breaks: 10/19/2004 and 9/26/2008.

$2 \mathrm{p}$ values in parenthesis.

${ }^{3}$ DW refers to Durbin-Watson statistics.

Table 11: Regression with attack types ${ }^{1,2}(10 / 11 / 2004-12 / 31 / 2015)$

\begin{tabular}{|c|c|c|c|c|}
\hline Variable & & $\gamma_{0}$ & $\gamma_{1}$ & $\mathrm{DW}^{3}$ \\
\hline \multirow[t]{6}{*}{ Attack Type } & Armed Assault & $\begin{array}{c}0.0004 \\
(0.7751)\end{array}$ & $\begin{array}{l}-0.0004 \\
(0.7753)\end{array}$ & \multirow[t]{6}{*}{2.0049} \\
\hline & Assassination & $\begin{array}{c}0.0011 \\
(0.7201)\end{array}$ & $\begin{array}{c}0.0033 \\
(0.2963)\end{array}$ & \\
\hline & Bombing & $\begin{array}{c}0.0009 \\
(0.4044)\end{array}$ & $\begin{array}{l}-0.0008 \\
(0.4248)\end{array}$ & \\
\hline & Facilities/Infrastructure & $\begin{array}{c}-0.0018 \\
(0.4705)\end{array}$ & $\begin{array}{c}-0.0040 \\
(0.0963)^{* * *}\end{array}$ & \\
\hline & Hostage Taking & $\begin{array}{c}-0.0002 \\
(0.9062)\end{array}$ & $\begin{array}{c}0.0019 \\
(0.2551)\end{array}$ & \\
\hline & Other & $\begin{array}{c}0.0042 \\
(0.2095)\end{array}$ & $\begin{array}{c}0.0008 \\
(0.7968)\end{array}$ & \\
\hline
\end{tabular}

${ }^{1} \mathrm{p}$ values in parenthesis.

${ }^{2}$ Coefficient is statistically different from zero *** at $10 \%$.

${ }^{3} \mathrm{DW}$ refers to Durbin-Watson statistics.

Likewise, terror attacks that occurred in the east (Eastern and Southeastern Anatolia) were no different from those that that occured in the west (Aegean, Black Sea, Central Anatolia, Marmara, and the Mediterranean):

Finally, in the third hypothesis, I ask: are all terror attacks alike in the sense that when they are classified into subgroups according to their attack types, does each type have the same impact on the stock market? Here, due to the singularity problems, the structural break test could not be applied. While 10/11/2004 and $9 / 26 / 2008$ were the two break dates common to most regressions, constrained by the limited number of observations for some attack types, I run the regression for the period between 10/11/2004 and 12/31/2015. The results presented in Table 11 shows that the stock market reacts only to the facility/infrastructure attacks. This suggests that investors are likely to view facility/infrastructure attacks as a threat to their investments. This is expected because when the attack type is facility/infrastructure, the investors are likely to think that terrorists have changed their tactics and start worrying about their own investment.

\section{CONCLUSIONS}

This paper investigates the effects of terror attacks, if any, on the Turkish stock market between January 2000 and December 2015. Although an event study analysis has been the most popular methodology in the related literature, in this paper, I have implemented the time series regression analysis, which is necessitated by the continuous stream of terror acts in Turkey. To allow for potential shifts in the relation, Bai-Perron tests of $L+1$ vs. $L$ sequentially determined breaks were implemented.

The analysis shows that terrorism imposed a significant negative effect on the stock market returns for the period of 2000-2004 but this effect vanished for the period of 2004-2015. While the desensitization over time may be given as one immediate explanation due to the high frequency of terror incidents, two alternative explanations can be given, each relates to the state of the Turkish financial system. 
First, the stock market might have better absorbed the shocks, which could be attributed to the strict measures implemented on the financial system after 2001 crisis and improved political stability among many other factors. Second, as its integration with the international stock markets increased over time; the stock market might have become more resilient to the negative shocks due to this better integration.

While the location of an attack did not matter and hence appears to be unimportant for the impact of terrorism on the stock market, the attack type did so. In fact, among various attack types, facility/infra- structure attacks were the only attacks that imposed a significant negative impact on the stock market returns.

Overall, these findings confirm the intuition that the effect of terrorism may differ across countries. The stability of the financial system and its higher integration with the international counterparts can make the stock market become desensitized to terror. Yet, even in this case, the stock market may be selective in its response to different attack types.

\section{END NOTES}

'According to 2014 Global Terrorism Index Report, the number of victims killed has increased five times since 2000. http://economicsandpeace.org/wp-content/uploads/2015/06/Global-Terrorism-Index-Report-2014.pdf.

${ }^{2}$ Dow Jones Industrial Average fell by 684.71 points, the biggest one day loss in its history. http://money.cnn. com/2006/09/08/markets/markets_fiveyearslater/index.htm?postversion=2006090817 .

${ }^{3}$ More details can be found at http://www.borsaistanbul.com/en/corporate/about-borsa-istanbul/milestones-in-borsa-istanbul-history .

${ }^{4}$ See Capital Market Board of Turkey's Annual Report 2014 at http://www.cmb.gov.tr/displayfile.aspx?action=displayfile\&pageid=17\&fn=17.pdf\&submenuheader=null and Turkish Capital Markets 2008 Report at https:// www.tspb.org.tr/wp-content/uploads/2015/08/AIM_Yayin_ve_Raporlar_Arastirma_Raporlari_TCMBI_Report_2008.pdf.

${ }^{5}$ Although popular, the drawback of this methodology is that it imposes certain restrictions on the behavior of returns.

\section{REFERENCES}

Abadie, A. and Gardeazabal, J. (2003) "The Economic costs of conflict: A case study of the Basque Country" American Economic Review, 93(1):113-132.

Abadie, A. and Gardeazabal, J. (2008)“Terrorism and the world economy" European Economic Review, 52(1):1-27.

Aksoy, M. (2014) "The Effects of Terrorism on Turkish Stock Market" Ege Academic Review, 14(1):31-41.

Alam, A. (2012) "Terrorism and Stock Market Development: Causality Evidence from Pakistan" Journal of Financial Crime, 20(1):116-128.

Arin, K. P., Ciferri, D., and Spagnolo, N. (2008) "The price of terror: The effects of terrorism on stock market returns and volatility" Economics Letters, 101(3):164-167.

Arshad, S. (2017) "Stock Markets in Islamic Countries. An Inquiry into Volatility, Efficiency" Alam et al. (eds.), Switzerland, Springer Nature.
Aslam, F. and Kang, H. G. (2015)“How different terrorist attacks affect stock markets" Defence and Peace Economics, 26(6):634-648.

Aslam, F., Kang, H. G., Mohti, W., Rafique, A., and Salman, A. (2015) "The impact of terrorism on financial markets: evidence from Asia"The Singapore Economic Review, 60(5):1-22.

Bai, J. (1997) "Estimating multiple breaks one at a time" Econometric theory, 13(03):315-352.

Bai, J. and Perron, P. (1998) "Estimating and testing linear models with multiple structural changes" Econometrica, 66:47-78.

Barros, CP, GM Caporale and LA Gil-Alana (2009) "Basque terrorism: Police action, political measures and the influence of violence on the stock market in the basque country" Defence and Peace Economics, 20:287-301. 
Brounen, D. and Derwall, J. (2010) "The Impact of Terrorist Attacks on International Stock Markets" European Financial Management, 16(4):585-598.

Brown, S. J., \& Warner, J. B. (1980) "Measuring security price performance" Journal of financial economics, 8(3):205-258.

Brown, S. J. ve Warner, J.B. (1985) "Using Daily Stock Returns: The Case of Event Studies" Journal of Financial Economics, 14(1):3-31.

Buesa, M., Valiño, A., Heijs, J., Baumert, T., \& Gomez, J. G. (2007) "The Economic Cost of March 11: Measuring the direct economic cost of the terrorist attack on March 11, 2004 in Madrid" Terrorism and Political Violence, 19(4):489-509.

Chen, A.H. and Siems, T.F. (2004) “The Effects of Terrorism on Global Capital Markets" European Journal of Political Economy, 20(2):349-366.

Crain, N. V., \& Crain, W. M. (2006) "Terrorized economies" Public Choice, 128(1-2):317-349.

Drakos, K. (2010) "Terrorism activity, investor sentiment, and stock returns" Review of Financial Economics, 19(3):128-135.

Drakos, K. and Kutan, A. M. (2003) "Regional effects of terrorism on tourism in three Mediterranean countries" Journal of Conflict Resolution, 47(5):621-641.

Dravid, A. R. (1987) "A Note on the Behavior of Stock Returns around Ex-Dates of Stock Distributions" The Journal of Finance, 42(1):163-168.

Eckstein, Z. and Tsiddon, D. (2004) "Macroeconomic Consequences of Terror: Theory and the Case of Israel" Journal of Monetary Economics, 51(5):971-1002.

Eldor, R. and Melnick, R. (2004) "Financial Markets and Terrorism" European Journal of Political Economy, 20(2):367-386.

Eldor, R. R., Hauser, S., Kroll, Y., and Shoukair, S. (2012) "Financial markets and terrorism: The perspective of the two sides of the conflict" Journal of Business Administration Research, 1:18-29.

Enders, W. and Olson, E. (2012) "Measuring the economic costs of terrorism" The Oxford Handbook of the Economics of Peace and Conflict, 874.

Eruygur, A. Ç. and Omay, T. (2014) "Terrorism and the Stock Market: A Case Study for Turkey Using STR Models" Journal of Reviews on Global Economics, 3:220227.

Essaddam, N. and Karagianis, J. M. (2014) "Terrorism, country attributes, and the volatility of stock returns" Research in International Business and Finance, 31:87-100.
Fama, E. F., Fisher, L., Jensen, M. C. and Roll, R. (1969) "The Adjustment of Stock Prices to New Information" International Economic Review, 10(1):1-21.

Gaibulloev, K. and Sandler, T. (2008) "Growth consequences of terrorism in Western Europe" Kyklos, 61(3):411-424.

Gaibulloev, K. and Sandler, T. (2009) "The impact of terrorism and conflicts on growth in Asia" Economics \& Politics, 21(3):359-383.

Karolyi, G. A. (2006) "The consequences of terrorism for financial markets: What do we know?" Ohio State University, Charles A. Dice Center for Research in Financial Economics.

Karolyi, G. A. and Martell, R. (2010) "Terrorism and the stock market" International Review of Applied Financial Issues and Economics, (2):285-314.

Kasman, A., Vardar, G., Okan, B., and Aksoy, G. (2009) "The Turkish Stock Market Integration with Developed and Emerging Countries' Stock Markets: Evidence from Cointegration Tests with and without Regime Shifts" Review of Middle East Economics and Finance, 5(1):24-49.

Lyon, J. D., Barber, B. M., and Tsai, C. L. (1999) “Improved Methods for Tests of Long-Run Abnormal Stock Returns" The Journal of Finance, 54(1):165-201.

Mlodkowski, P., \& Tastulekova, A. (2012) “Performance of Capital Markets in the EU and in Turkey: Cointegration Analysis" European Integration Studies, (6):160-167.

Nguyen, AP and CE Enomoto (2009) "Acts of terrorism and their impacts on stock index returns and volatility: The cases of the Karachi and Tehran stock exchanges" International Business \&Economics Research Journal, 8:75-86.

Nikkinen, J, MM Omran, P Sahlström, and J Äijö (2008) "Stock returns and volatility following the September 11 attacks: Evidence from 53 equity markets" International Review of Financial Analysis, 17:27-46.

Park, C. Y. and Lee, J. W. (2011) "Financial integration in emerging Asia: Challenges and prospects" Asian Economic Policy Review, 6(2):176-198.

Pound, J., Zeckhauser, R. (1990) "Clearly Heard on the Street: The effect of takeover rumors on stock prices" Journal of Business, 63(3):291-308.

Zussman, A. and Zussman, N. (2006) "Assassinations: Evaluating the effectiveness of an Israeli counterterrorism policy using stock market data" The Journal of Economic Perspectives, 20(2):193-206. 